\title{
Sodium sulfite (SoS) as decontamination strategy for Fusarium-toxin contaminated maize and its impact on immunological traits in pigs challenged with lipopolysaccharide (LPS)
}

\author{
Anh-Tuan Tran ${ }^{1}$ - Jeannette Kluess ${ }^{1}$ (D) - Susanne Kersten ${ }^{1} \cdot$ Andreas Berk $^{1}$ - Marleen Paulick ${ }^{1}$ - Dian Schatzmayr ${ }^{2}$. \\ Sven Dänicke ${ }^{1} \cdot$ Jana Frahm $^{1}$
}

Received: 3 December 2019 / Revised: 16 July 2020 / Accepted: 22 July 2020 / Published online: 9 September 2020

(C) The Author(s) 2020

\begin{abstract}
The main objective of this study was to evaluate the effects of sodium sulfite (SoS) treatment of maize and its impact on the porcine immune system in the presence of an LPS-induced systemic inflammation. Control maize (CON) and Fusariumtoxin contaminated maize (FUS) were wet-preserved (20\% moisture) for 79 days with (+) or without (-) SoS and then included at $10 \%$ in a diet, resulting in four experimental groups: CON-, CON+, FUS-, and FUS+ with deoxynivalenol (DON) concentrations of $0.09,0.05,5.36$, and $0.83 \mathrm{mg} \mathrm{DON} / \mathrm{kg}$ feed, respectively. After 42-day feeding trial (weaned barrows, $n=20 /$ group), ten pigs per group were challenged intraperitoneally with either $7.5 \mu \mathrm{g}$ LPS/kg BW or placebo $(0.9 \% \mathrm{NaCl})$, observed for $2 \mathrm{~h}$, and then sacrificed. Blood, mesenteric lymph nodes, and spleen were collected for phenotyping of different $\mathrm{T}$ cell subsets, $\mathrm{B}$ cells, and monocytes. Phagocytic activity and intracellular formation of reactive oxygen species (ROS) were analyzed in both polymorphonuclear cells (PMN) and peripheral blood mononuclear cells (PBMC) using flow cytometry. Our results revealed that the impact of DON was more notable on $\mathrm{CD}^{+} \mathrm{CD} 4^{+} \mathrm{CD} 8^{+} \mathrm{T}$ cells in lymphoid tissues rather than in blood $\mathrm{T}$ cells. In contrast, SoS treatment of maize altered leukocyte subpopulations in blood, e.g., reduced the percentage and fluorescence signal of CD8 ${ }^{\text {high }} \mathrm{T}$ cells. Interestingly, SoS treatment reduced the amount of free radicals in basal ROS-producing PMNs only in LPSchallenged animals, suggesting a decrease in basal cellular ROS production $\left(p_{\text {SoS } * \text { LPS }}=0.022\right)$.
\end{abstract}

Keywords Sodium sulfite $\cdot$ Deoxynivalenol $\cdot$ Immune cells $\cdot$ Lipopolysaccharide $\cdot$ Piglet

\begin{tabular}{l} 
Abbreviations \\
CON $\quad$ Control maize \\
DON $\quad$ Deoxynivalenol \\
FUS $\quad$ Fusarium-toxin contaminated maize \\
LOD Level of detection \\
LPS $\quad$ Lipopolysaccharide \\
Electronic supplementary material The online version of this article \\
(https://doi.org/10.1007/s12550-020-00403-x) contains supplementary \\
material, which is available to authorized users. \\
\hline
\end{tabular}

Jeannette Kluess

jeannette.kluess@ fli.de

1 Institute of Animal Nutrition, Friedrich-Loeffler-Institut (FLI), Federal Research Institute for Animal Health, Braunschweig, Germany

2 BIOMIN Holding GmbH, BIOMIN Research Center, Tulln, Austria

$\begin{array}{ll}\text { MFI } & \text { Mean fluorescence intensity } \\ \text { PBMC } & \text { Peripheral blood mononuclear cells } \\ \text { PMN } & \text { Polymorphonuclear cells } \\ \text { ROS } & \text { Reactive oxygen species } \\ \text { SoS } & \text { Sodium sulfite }\end{array}$

\section{Introduction}

Deoxynivalenol (DON) belongs to the B-trichothecene mycotoxins produced from Fusarium species. Among the farm animals, pigs are known as the most susceptible species to DON exposure, responding with a reduction in feed intake and lower weight gain, resulting in economic losses for the farmer (EFSA 2004). In the temperate climate regions, DON often occurs in cereal grains, especially wheat and maize (EFSA 2013). Moreover, DON contamination in the field cannot 
completely be avoided due to weather conditions. Additionally, DON is only negligibly degraded by feed processing and therefore decontamination methods are required to inactivate DON before cereal grains are used for the production of complete feeds (Awad et al. 2010). Although various decontamination strategies were investigated, an effective procedure is still needed (Kabak et al. 2006; He et al. 2010). Moreover, easy-to-use inactivation procedures are required at farm level where cereals are directly used for feeding. The simple wet preservation of Fusariumtoxin contaminated cereal grains with sodium sulfite $\left(\mathrm{Na}_{2} \mathrm{SO}_{3}, \mathrm{SoS}\right)$ or sodium metabisulfite $\left(\mathrm{Na}_{2} \mathrm{~S}_{2} \mathrm{O}_{5}, \mathrm{SBS}\right)$, using a defined moisture content and acidification with propionic acid, has shown to decrease DON concentration via the formation of sulfonated derivatives of DON, the socalled DON sulfonates (DONS) (Young et al. 1987; Schwartz et al. 2013; Schwartz-Zimmermann et al. 2014; ). The SoSand SBS-induced decrease of DON concentration in cereal grains was reflected by a concomitant detection of low DON concentrations in blood and other physiological specimen (Dänicke et al. 2005; Dänicke et al. 2008; Paulick et al. 2018; Tran et al. 2018a) as well as an improved performance comparable with that observed in control groups fed noncontaminated diets (Paulick et al. 2018).

Despite positive effects on the piglet performance, several non-specific effects of SBS treatment were recorded when pigs were fed SBS-treated diets irrespective of DON contamination (Dänicke et al. 2008; Dänicke et al. 2012), such as a plasma protein increase, stimulated liver function as determined by the ${ }^{13} \mathrm{C}$-methacetin breath test, and an increased stimulation capacity of peripheral blood mononuclear cells (PBMC). The liver, besides its function as a main metabolic organ, also acts as a secondary immunological organ, which initiates and mediates the acute phase response as an innate immune mechanism (Crispe 2009); therefore, a consequential interference of SBS treatment with the immune system remains to be elucidated.

Lipopolysaccharides (LPS) are a major component of the cell wall of Gram-negative bacteria (Palsson-McDermott and O'Neill 2004) and are known as pathogen-associated molecular patterns (PAMPs), capable of inducing an acute phase response. The latter consists of immediate effects such as releasing soluble mediators like tumor necrosis factor-alpha $(\mathrm{TNF}-\alpha)$ and interferon- $\beta$ (IFN- $\beta$ ) from immune cells into the circulation as well as secondary inflammatory effects, for example, an increased aspartate aminotransferase (AST) activity and bilirubin concentration leading to tissue and cellular injuries (Dänicke et al. 2013; Kuzmich et al. 2017). Due to these characteristics, LPS is experimentally often used as a defined immune challenge in animal models investigating the responsiveness of the immune system (Wyns et al. 2015).

Applying this LPS model, we could show recently that both, SoS treatment of maize and LPS-induced systemic inflammation, altered the differential white blood cell counts (total leukocytes, lymphocytes, granulocytes, monocytes) of piglets in an interactive manner (Tran et al. 2018b). However, based on this general evaluation of the white blood count, no information about possible mechanisms of these global changes could be gathered. Thus, lymphocytes were further phenotyped investigating the effects of SoS wet-preservation on lymphocyte subpopulations, such as Thelper and cytotoxic $\mathrm{T}$ cells. As granulocytes and monocytes directly or indirectly influence the number and function of lymphocytes and other immune cells, we further examined their main functions such as phagocytic activity and capability to mount an oxidative burst.

\section{Material and methods}

\section{Animal experiment}

The experiment was performed at the experimental station of the Institute of Animal Nutrition, Friedrich-Loeffler-Institute (FLI), Brunswick, Germany, in compliance with the European Community regulations concerning the protection of experimental animals and was approved by the Lower Saxony State Office for Consumer Protection and Food Safety (LAVES), Germany (file number: 33.92-42502-04-13/1153).

All samples were derived from a weaned piglet trial, set up in a $2 \times 2 \times 2$ factorial design (maize batch $\times$ sodium sulfite $\times$ LPS challenge) comprising an acute LPS challenge at the end of a 42-day feeding period (Tran et al. 2018b). Briefly, two maize batches were produced, a control batch $(\mathrm{CON})$ with a background contamination of the two major Fusarium mycotoxins deoxynivalenol (DON) and zearalenone (ZEN) and a batch experimentally inoculated with Fusarium spores (FUS), containing high levels of DON and ZEN (Paulick et al. 2015). Each batch of maize kernels was subdivided and wetpreserved (20\% moisture, $15 \mathrm{~g}$ propionic acid/kg maize), either with or without (+/-) the addition of $5 \mathrm{~g} \mathrm{SoS} / \mathrm{kg}$ maize ( $\mathrm{Na}_{2} \mathrm{SO}_{3}$ : CAS-no. 7757-83-7, $\geq 98 \%$, p.a., ACS, water free; Carl Roth GmbH \& Co KG, Karlsruhe/Germany) for 79 days. After preservation, the resulting four maize batches were ground and blended into experimental diets containing 35\% barley, $27.3 \%$ wheat, $10 \%$ maize, $23 \%$ soybean meal, $1.5 \%$ soya bean oil, $1 \%$ vitamin and mineral premix, $2.2 \%$ synthetic amino acids (HCl-lysine, DL-methionine, L-threonine, Ltryptophan), and a commercial phytase. This resulted in four experimental diets: $\mathrm{CON}-$ (control maize, without SoS; $0.09 \mathrm{mg} \mathrm{DON} / \mathrm{kg}$ feed, ZEN < LOD), CON+ (control maize, with SoS; $0.05 \mathrm{mg}$ DON/kg feed, ZEN < LOD), FUS- (contaminated maize, without SoS; $5.36 \mathrm{mg}$ DON $/ \mathrm{kg}$ feed, $0.29 \mathrm{mg} Z \mathrm{ZEN} / \mathrm{kg}$ feed), and FUS+ (contaminated maize, with $\mathrm{SoS} ; 0.83 \mathrm{mg} \mathrm{DON} / \mathrm{kg}$ feed, $0.27 \mathrm{mg} \mathrm{ZEN} / \mathrm{kg}$ feed). 
Eighty male castrated crossbred piglets $(7.59 \pm 0.92$ $\mathrm{kg}$ ) were allotted equally — based on body weight - to the four experimental groups, group-housed (4 piglets/ pen; $20 \mathrm{pigs} /$ group $=5 \mathrm{pens} /$ group $)$, and offered feed and water for ad libitum consumption. After 42 days, ten pigs of each dietary group were allocated to the challenge trial, while the remaining pigs $(n=10 /$ diet $)$ were slaughtered for further aspects (Tran et al. 2018a). Detailed procedures of the LPS challenge were described in Tran et al. (2018b). Briefly, these piglets were injected intraperitoneally either with $7.5 \mu \mathrm{g} \mathrm{LPS} / \mathrm{kg} \mathrm{BW}$ (Escherichia coli serotype O111:B4, Sigma-Aldrich, Steinheim, Germany, L 2630; CON-/LPS, CON+/LPS, FUS-/LPS, FUS+/LPS; $n=5$ per treatment group) or with $0.9 \% \mathrm{NaCl}$ as placebo (volume $\sim 6.5 \mathrm{~mL} /$ animal; $\mathrm{CON}-/ \mathrm{NaCl}, \mathrm{CON}+/ \mathrm{NaCl}, \mathrm{FUS}-/ \mathrm{NaCl}, \mathrm{FUS}+/ \mathrm{NaCl} ; n=$ 5 per treatment group). Two hours after the challenge, animals were electrically stunned, blood samples taken immediately from neck vessels for further analyses, and pigs then sacrificed by exsanguination. Pigs were immediately dissected, tissue samples of mesenteric lymph nodes and spleen collected and directly placed into a cardioplegia solution (Custodiol, Dr. Franz Köhler Chemie GmbH, Bensheim, Germany) until cell preparation procedures.

\section{Analytical methods}

\section{Cell preparations}

Cells from mesenteric lymph nodes were isolated by a modified method according to Solano-Aguilar et al. (2000). Briefly, serosa and surrounding tissues from mesenteric lymph nodes were removed. Then, mesenteric lymph nodes were transferred into a culture dish with cold PBS (phosphatebuffered saline), cut medial and longitudinal with a scalpel to obtain a cell suspension. The suspension was filtered with a sieve kept on ice and centrifuged at $300 \mathrm{xg}$ at $4{ }^{\circ} \mathrm{C}$ for $10 \mathrm{~min}$. Next, the supernatant was removed and the pellet was resuspended in HEPES-buffered saline (HBS). After one filtration, this cell suspension was used for staining with antibodies for flow cytometry.

Isolation of splenic cells was performed according to Renner et al. (2012). In brief, spleen tissue was minced with a scalpel, placed into sterile HEPES-buffered solution (HBS), and smoothed through a cell strainer into Petri dishes for erythrocytes' lysis. After centrifugation $(250 \times g, 5 \mathrm{~min})$ and washing in HBS, cells were resuspended in RPMI 1640 medium, supplemented with fetal bovine serum, penicillin-streptomycin, mercapto-ethanol, and L-glutamine (Biochrom AG, Berlin, Germany). Subsequently, these cells were stained with antibodies for flow cytometric analysis.

\section{Phenotyping of leukocyte subsets}

For phenotyping of leukocyte subsets, single cell suspensions $\left(1 \times 10^{6}\right.$ cells $/ \mathrm{mL}$, in duplicate/sample) of cells from either mesenteric lymph node or splenocytes or $50 \mu 1$ EDTA whole blood were incubated with monoclonal antibodies (Table 1) as double stain (monocytes, B cells) or triple stain ( $\mathrm{T}$ cells) for $30 \mathrm{~min}$ on ice in the dark. After washing, the cell suspensions from tissue samples were resuspended in HBS and analyzed with a FACSCanto ${ }^{\mathrm{TM}}$ II flow cytometer (BD Biosciences, San Jose, CA, USA). The whole blood samples were further processed by incubating for 10 min with lysis buffer (BD Pharm Lyse, BD Biosciences, San Jose, CA, USA), centrifugation (5 min, $250 \times g, 4{ }^{\circ} \mathrm{C}$ ), and resuspension in HBS.

For measurement, an acquisition gate was set for blood peripheral mononuclear cells $(\mathrm{PBMC}=$ lymphocytes, monocytes) according to its side scatter and forward scatter characteristics for each tissue (blood, spleen, mesenteric lymph node). A minimum of 10,000 cells was evaluated with FACSDiva $^{\mathrm{TM}}$ software 6.1.3 (BD Biosciences, San Jose, CA, USA). The gating strategies for T cells (S1) and B cells (S2) are detailed in supplementary material.

$\mathrm{B}$ cells $\left(\mathrm{CD} 21^{+}\right)$and monocytes $\left(\mathrm{CD} 14^{+}\right)$were characterized by the expression of their respective epitope. Four $\mathrm{T}$ cell subsets were defined as follows: $\mathrm{CD}^{+} \mathrm{CD}^{+} \mathrm{CD} 8^{-}$( $\mathrm{T}$ helper cells), $\mathrm{CD}^{+} \mathrm{CD}^{-} \mathrm{CD}^{+}$(cytotoxic $\mathrm{T}$ cells), $\mathrm{CD}^{+}{ }^{+} \mathrm{CD} 4^{-} \mathrm{CD} 8^{-}$ (undifferentiated $\mathrm{T}$ cells), and $\mathrm{CD}^{+} \mathrm{CD}^{+}{ }^{+} \mathrm{CD} 8^{+}$(double-positive $\mathrm{T}$ cells). The expression density of each $\mathrm{CD}$ epitope per cell was characterized by their mean fluorescence intensity (MFI). The total $\mathrm{CD}^{+}{ }^{+} \mathrm{CD} 4{ }^{-} \mathrm{CD} 8^{+}$cells were further separated in two subsets according to their fluorescence intensity classifying cells of low $\left(\mathrm{CD} 8^{\text {low }}\right)$ or high expression $\left(\mathrm{CD} 8^{\text {high }}\right)$ of the CD8 marker. Furthermore, the ratio between $\mathrm{CD}^{+}{ }^{+} \mathrm{CD} 4^{+} \mathrm{CD}^{-}$and $\mathrm{CD}^{+}{ }^{+} \mathrm{CD} 4^{-} \mathrm{CD} 8^{+}$cells $\left(\mathrm{CD} 4^{+} / \mathrm{CD} 8^{+}\right)$ was calculated.

\section{Intracellular production of reactive oxygen species}

Dihydrorhodamine 123 (DHR, Molecular Probes, Eugene, Oregon, USA) is a non-fluorescent molecule capable of passing the cell membrane and can be oxidized to its fluorescent product rhodamine $123\left(\mathrm{R} 123^{+}\right)$by ROS. Thus, DHR is routinely used to measure intracellular ROS generation by flow cytometry. The capacity of ROS production in polymorphonuclear cells $(\mathrm{PMN}=$ granulocytes $)$ and PBMC was determined using a FACSCanto ${ }^{\mathrm{TM}}$ II flow cytometer (BD Biosciences, San Jose, CA, USA). Fifty microliters of whole blood samples (in duplicates) were incubated for $15 \mathrm{~min}$ at 37 ${ }^{\circ} \mathrm{C}$ with $40 \mathrm{mM}$ DHR alone (basal production) or with $20 \mathrm{nM}$ tetradecanoyl-12,13-phorbol acetate (TPA, Sigma Aldrich, Taufkirchen, Germany) in order to stimulate an oxidative burst. After 10 min lysis of erythrocytes (BD Pharm Lyse, 
Table 1 List of monoclonal antibodies (mAb) as applied in flow cytometric analysis of leukocytes (FACS ${ }^{\mathrm{TM}}$ II Canto flow cytometer, BD Biosciences, San Jose, CA, USA)

\begin{tabular}{llll}
\hline Specificity & mAb & Fluorescent dye & Manufacturer \\
\hline CD3 & Mouse Anti-Pig CD3 & Alexa Fluor®647 & BD Bioscience, San Jose, USA \\
CD4 & Mouse Anti-Pig CD4 & FITC & AbD, seroTEC, Oxford, UK \\
CD8 & Mouse Anti-Pig wCD8 & RPE & AbD, seroTEC, Oxford, UK \\
CD21 & Mouse Anti-Human CD21 & PE & BD Biosciences, San Jose, USA \\
CD14 & Mouse Anti-Pig CD14 & FITC & AbD, seroTEC, Oxford, UK \\
Isotype control & mouse IgG1 & Alexa Fluor®647 & AbD, seroTEC, Oxford, UK \\
Isotype control & mouse IgG2a & RPE & AbD, seroTEC, Oxford, UK \\
Isotype control & mouse IgG2b & FITC & AbD, seroTEC, Oxford, UK \\
\hline
\end{tabular}

BD Biosciences, San Jose, CA, USA), cells were washed with HBS and the formation of $\mathrm{R} 23^{+}$was measured. At least 10,000 cells of each population were analyzed selecting the appropriate gates. Percentage of ROS-producing PMN and PMBC and the intracellular level of ROS production (MFI) were determined.

\section{Phagocytosis assay}

The phagocytic activity of PMN and PBMC was assessed by a commercial kit, Phagotest $^{\mathrm{TM}}$ (Glycotope Biotechnology, Heidelberg, Germany) according to the manufacturer's instructions. Briefly, $100 \mu \mathrm{l}$ heparinized whole blood (in duplicates) was incubated with FITC-labelled $E$. coli bacteria for either $10 \mathrm{~min}$ at $37^{\circ} \mathrm{C}$ or $10 \mathrm{~min}$ in an ice bath for negative control. After quenching and lysis of erythrocytes, cells were washed and propidium iodide (PI) was added to stain the DNA. Fluorescence intensity was measured using FACSCanto $^{\mathrm{TM}}$ II (BD Biosciences, San Jose, CA, USA). PMN and PBMC cells were gated according to their size and granularity based on measurements of forward and size scatter (S1). At least 10,000 cells of each population were analyzed with FACSDiva ${ }^{\mathrm{TM}}$ software 6.1 .3 (BD Biosciences, San Jose, CA, USA). Percentage of phagocyting $\mathrm{PMN}$ and $\mathrm{PMBC}$ as well as the phagocytic capacity per cell was characterized by their MFI.

\section{Statistics}

Data were statistically analyzed as a $2 \times 2 \times 2$ factorial design, using PROC MIXED (SAS Institute 2004), with maize batch (control maize vs. Fusarium-toxin contaminated maize [FUS]), SoS treatment (with vs. without $\mathrm{Na}_{2} \mathrm{SO}_{3}$ [SoS]), and LPS challenge ( $\mathrm{NaCl}$ vs. LPS [LPS]) as well as all their interactions (FUS*SoS, FUS*LPS, SoS*LPS, FUS*SoS*LPS) as fixed factors. Differences were deemed significant at $p<0.05$ and Student's $t$ test was applied as post hoc procedure. Results are presented as least square means (LSmeans) and pooled standard error of the mean (PSEM).

\section{Results}

\section{T cell subsets in peripheral blood and lymphatic organs}

T cells in peripheral blood and lymphatic tissues were characterized by their expression of the CD3 protein complex and further differentiated in four subsets according to the coexpression of CD4 and CD8 epitopes. The distribution of T cell phenotypes as percentage of all $\mathrm{CD}^{+}$cells in blood, mesenteric lymph node, and spleen, including their respective $p$ values, are presented in Fig. 1.

In blood (Fig. 1a), we observed a significant impact of the factor FUS ( $p_{\text {FUS }}=0.015$ ), with an increase in double-positive cells $\left(\mathrm{CD}^{+} \mathrm{CD}^{+} \mathrm{CD}^{+}\right)$in pigs receiving FUS-contaminated diets $(8.4$ vs. $11.2 \%)$. Furthermore, $\mathrm{CD}^{+}$cells $\left(\mathrm{CD}^{+} \mathrm{CD}^{+} \mathrm{CD}^{-}\right)$were decreased by SoS treatment $\left(p_{\mathrm{SoS}}=\right.$ $0.010,33.7$ vs. $26.6 \%$ ) but increased in LPS-challenged pigs $\left(p_{\text {LPS }}=0.003,26.0\right.$ vs. $\left.34.2 \%\right)$. No interactions were evident in blood $\mathrm{T}$ cell subsets.

In mesenteric lymph node (Fig. 1b), a significant interaction between FUS and LPS challenge $\left(p_{\text {FUS } * \text { LPS }}=0.047\right)$ was observed for the double-positive cells $\left(\mathrm{CD}^{+} \mathrm{CD}^{+} \mathrm{CD}^{+}\right)$due to a decline in the pooled group $\mathrm{FUS} / \mathrm{NaCl}$ while the other three groups remained unaltered. Moreover, $\mathrm{CD}^{+}$cells $\left(\mathrm{CD}^{+} \mathrm{CD}^{-} \mathrm{CD}^{+}\right)$significantly displayed an interaction between FUS, SoS treatment, and LPS challenge ( $p_{\text {FUS*SoS*LPS }}$ $=0.039$ ) due to a clear increase in group FUS-/LPS and a strong reduction in group FUS+/LPS while the other groups remained unchanged.

In spleen (Fig. 1c), the percentage of double-negative cells $\left(\mathrm{CD}^{+} \mathrm{CD}^{-} \mathrm{CD}^{-}\right)$was lower in pooled groups $\mathrm{FUS} / \mathrm{NaCl}$, $\mathrm{CON} / \mathrm{LPS}$, and FUS/LPS compared with group $\mathrm{CON} / \mathrm{NaCl}$, which resulted in a significant interaction between the main factors FUS and LPS challenge ( $p_{\text {FUS*LPS }}=0.046$ ).

The intensity of the fluorescence signal as an indicator of cellular activity remained unaffected in total $\mathrm{CD}^{+} \mathrm{T}$ cells $(\mathrm{S} 3 \mathrm{a})$ in lymph node $\left(4.5 \pm 0.3 \times 10^{3}\right)$ and spleen $(3.1 \pm 0.8$ $\left.\times 10^{3}\right)$. However, in blood, statistical analysis revealed a significant increase of MFI in $\mathrm{CD}^{+}$cells due to FUS feeding $\left(p_{\mathrm{FUS}}=0.008\right)$. Factor SoS showed a contrasting effect $\left(\mathrm{p}_{\mathrm{SoS}}=\right.$ 
(a)

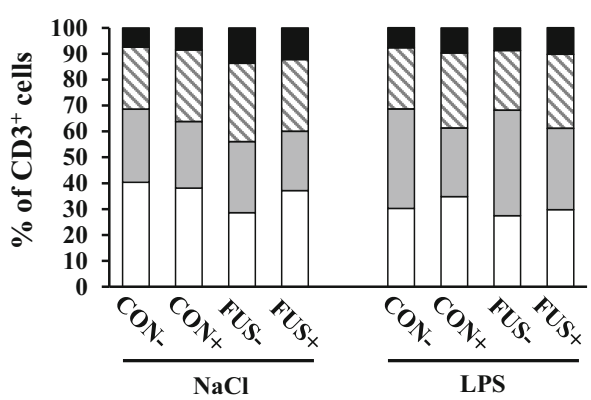

(c)

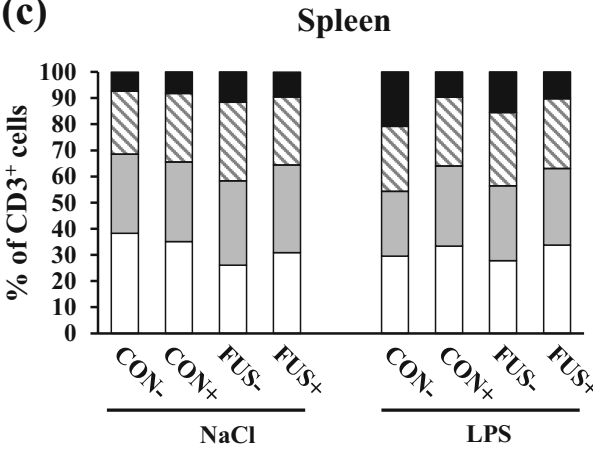

$\mathrm{CD3}^{+} \mathrm{CD}^{+} \mathrm{CD8}^{+} \quad \otimes \mathrm{CD3}^{+} \mathrm{CD}^{-} \mathrm{CDB}^{+}$

$\mathrm{CD3}^{+} \mathrm{CD}^{+} \mathrm{CD8}^{-}$
Blood

(b)

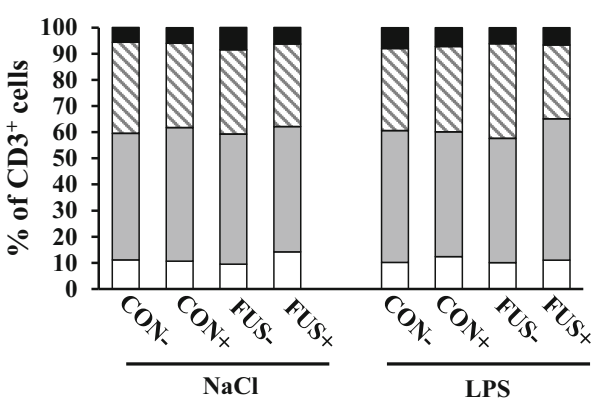

\begin{tabular}{|c|c|c|c|c|c|c|c|c|}
\hline & \multirow[b]{2}{*}{ PSEM } & \multicolumn{7}{|c|}{$p$-values } \\
\hline & & FUS & Sos & LPS & FUS*SoS & FUS*LPS & SoS*LPS & FUS*SoS*LPS \\
\hline \multicolumn{9}{|c|}{ Blood } \\
\hline $\mathrm{CD}^{+} \mathrm{CD}^{+} \mathrm{CD}^{+}$ & 1.6 & 0.015 & 0.507 & 0.227 & 0.531 & 0.078 & 0.388 & 0.659 \\
\hline $\mathrm{CD}^{+} \mathrm{CD} 4^{-} \mathrm{CD} 8^{+}$ & 2.3 & 0.415 & 0.073 & 0.436 & 0.350 & 0.273 & 0.152 & 0.317 \\
\hline $\mathrm{CD}^{+} \mathrm{CD} 4^{+} \mathrm{CD} 8^{-}$ & 3.6 & 0.717 & 0.010 & 0.003 & 0.958 & 0.306 & 0.184 & 0.660 \\
\hline $\mathrm{CD}^{+}{ }^{+} \mathrm{CD} 4^{-} \mathrm{CD} 8^{-}$ & 4.1 & 0.090 & 0.275 & 0.072 & 0.471 & 0.679 & 0.970 & 0.278 \\
\hline \multicolumn{9}{|c|}{ Mesenteric lymph node } \\
\hline $\mathrm{CD}^{+} \mathrm{CD}^{+}{ }^{+} \mathrm{CD} 8^{+}$ & 0.9 & 0.826 & 0.398 & 0.562 & 0.637 & 0.047 & 0.582 & 0.148 \\
\hline $\mathrm{CD}^{+} \mathrm{CD}^{-} \mathrm{CD}^{+}$ & 1.8 & 0.616 & 0.071 & 0.643 & 0.167 & 0.500 & 0.520 & 0.039 \\
\hline $\mathrm{CD} 3^{+} \mathrm{CD} 4^{+} \mathrm{CD} 8^{-}$ & 2.5 & 0.827 & 0.517 & 0.705 & 0.496 & 0.472 & 0.672 & 0.061 \\
\hline $\mathrm{CD}^{+} \mathrm{CD} 4^{-} \mathrm{CD} 8^{-}$ & 1.8 & 0.920 & 0.161 & 0.705 & 0.464 & 0.517 & 0.834 & 0.210 \\
\hline \multicolumn{9}{|c|}{ Spleen } \\
\hline $\mathrm{CD}^{+} \mathrm{CD}^{+}{ }^{+} \mathrm{CD} 8^{+}$ & 3.6 & 0.925 & 0.094 & 0.063 & 0.779 & 0.321 & 0.148 & 0.395 \\
\hline $\mathrm{CD}^{+} \mathrm{CD}^{-} \mathrm{CD}^{+}$ & 2.7 & 0.235 & 0.818 & 0.952 & 0.252 & 0.780 & 0.798 & 0.672 \\
\hline $\mathrm{CD}^{+}{ }^{+} \mathrm{CD} 4^{+} \mathrm{CD} 8^{-}$ & 3.0 & 0.371 & 0.367 & 0.131 & 0.610 & 0.764 & 0.570 & 0.484 \\
\hline $\mathrm{CD}^{+}{ }^{+} \mathrm{CD} 4^{-} \mathrm{CD} 8^{-}$ & 2.6 & 0.019 & 0.122 & 0.427 & 0.166 & 0.046 & 0.264 & 0.419 \\
\hline
\end{tabular}

PSEM: pooled standard error of means.
Fig. 1 Distribution pattern of four $\mathrm{T}$ cell subsets (\% of $\mathrm{CD}^{+}$cells) in blood (a), mesenteric lymph node (b), and spleen (c) in piglets receiving experimental diets for 5 weeks and subjected to a subsequent acute LPS challenge. Diets contained control (CON) or

0.001) with a decrease in MFI levels due to SoS treatment. In $\mathrm{CD}^{+}$cells, the MFI (S3b) was unaltered by any treatment with $2.0 \pm 0.1 \times 10^{3}$ in blood, $2.4 \pm 0.1 \times 10^{3}$ in lymph node, and $2.6 \pm 0.1 \times 10^{3}$ in spleen.

Although some alterations of $\mathrm{T}$ cell subpopulations were found in the specimen analyzed, the $\mathrm{CD} 4^{+} / \mathrm{CD} 8^{+}$ratio (Fig. 2) was only significantly affected by treatments in blood samples rather than spleen and mesenteric lymph node: SoS treatment $\left(p_{\text {SoS }}=0.003\right)$ decreased the $\mathrm{CD} 4^{+} / \mathrm{CD}^{+}$ratio due to a decrease in the $\mathrm{CD}^{+}$cells, whereas LPS $\left(p_{\mathrm{LPS}}=0.011\right)$ increased the ratio, likely due to the increase in $\mathrm{CD} 4^{+}$and constancy of $\mathrm{CD} 8^{+}$cells. There was no interaction between the main factors. Furthermore, $\mathrm{CD} 4^{+} / \mathrm{CD} 8^{+}$ratio differed significantly due to site of cell residence: the highest $\mathrm{CD} 4^{+} / \mathrm{CD}^{+}$ ratio was observed in the mesenteric lymph node, whereas the $\mathrm{CD} 4^{+} / \mathrm{CD}^{+}$ratio in blood and spleen appeared comparable $\left(p_{\text {Localization }}<0.001\right)$.

In pigs, $\mathrm{CD} 8^{+} \mathrm{T}$ cells are unique as they show two subpopulations with high and with low expression $\left(\mathrm{CD} 8^{\text {low }}\right.$ and CD $8^{\text {high }}$ ) of the CD8 subsets (Lunney and Pescovitz 1987; Gerner et al. 2009), denoting differences in cellular function. These subpopulations and their respective MFI in peripheral blood are displayed in Fig. 3. The main factor SoS treatment
Fusarium-toxin contaminated maize (FUS), wet-conserved with or without $5 \mathrm{~g} \mathrm{SoS} / \mathrm{kg}$ maize sodium sulfite $(+/-)$ and piglets were injected with $7.5 \mu \mathrm{g} \mathrm{LPS} / \mathrm{kg} \mathrm{BW}$ or $0.9 \% \mathrm{NaCl}$. Data represent LSmeans $(n=5)$ for each $\mathrm{T}$ cell subset

showed a significant effect on the percentage of both $\mathrm{CD} 8^{\text {low }}$ and $\mathrm{CD} 8^{\text {high }}$ cells: $\mathrm{CD} 8^{\text {low }}$ cells were increased whereas $\mathrm{CD} 8^{\text {high }}$ cells were conversely decreased (Fig. 3a). A significant interaction between FUS, SoS treatment, and LPS challenge was found for the MFI (Fig. 3b) of $\mathrm{CD} 8^{\text {low }}$ cells due to an increase in group FUS- $\mathrm{NaCl}$ and a drop in group FUS -/LPS, whereas the other groups remained unaltered. Changes in MFI of $\mathrm{CD} 8^{\text {high }}$ cells were also observed: MFI was increased in pigs receiving FUS-contaminated diets $(13.6 \times$ $10^{3}$ vs. $\left.15.6 \times 10^{3}\right)$, whereas a depressing effect of SoS treatment was shown $\left(15.7 \times 10^{3}\right.$ vs. $\left.13.5 \times 10^{3}\right)$. In mesenteric lymph node, there were no alterations in percentage and MFI of $\mathrm{CD} 8^{\text {low }}\left(67.4 \pm 5.8 \%, 2.7 \pm 0.2 \times 10^{3}\right)$ and $\mathrm{CD} 8^{\text {high }}$ cells $\left(32.5 \pm 5.8 \%, 8.1 \pm 0.4 \times 10^{3}\right)$. Similarly, the percentage and MFI of both $\mathrm{CD} 8^{\text {low }}$ and $\mathrm{CD} 8^{\text {high }}$ cells in spleen remained unaltered $\left(\mathrm{CD} 8^{\text {low }}: 86.3 \pm 3.6 \%, 2.0 \pm 0.1 \times 10^{3} ; \mathrm{CD} 8^{\text {high }}\right.$ : $13.5 \pm 3.5 \%, 9.3 \pm 1.0 \times 10^{3}$ ).

\section{B cell and monocytes in blood and lymphatic organs}

$\mathrm{B}$ cells were characterized by the expression of $\mathrm{CD} 21^{+}$ epitope. The percentage of $\mathrm{CD} 21^{+}$cells was altered in blood only (Fig. 4a), with a significant interaction between 
Fig. 2 Relationship between $\mathrm{T}$ helper and cytotoxic $\mathrm{T}$ cells $\left(\mathrm{CD}^{+}\right.$to $\mathrm{CD}^{+}$ratio) in blood, mesenteric lymph node, and spleen (LSMeans, $n=5$ ) in piglets receiving experimental diets for 5 weeks and subjected to a subsequent acute LPS challenge. Diets contained control (CON) or Fusarium-toxin contaminated maize (FUS), wet-conserved with or without $5 \mathrm{~g} \mathrm{SoS} / \mathrm{kg}$ maize sodium sulfite $(+/-)$ and piglets were injected with $7.5 \mu \mathrm{g}$ LPS $/ \mathrm{kg}$ $\mathrm{BW}$ or $0.9 \% \mathrm{NaCl}$

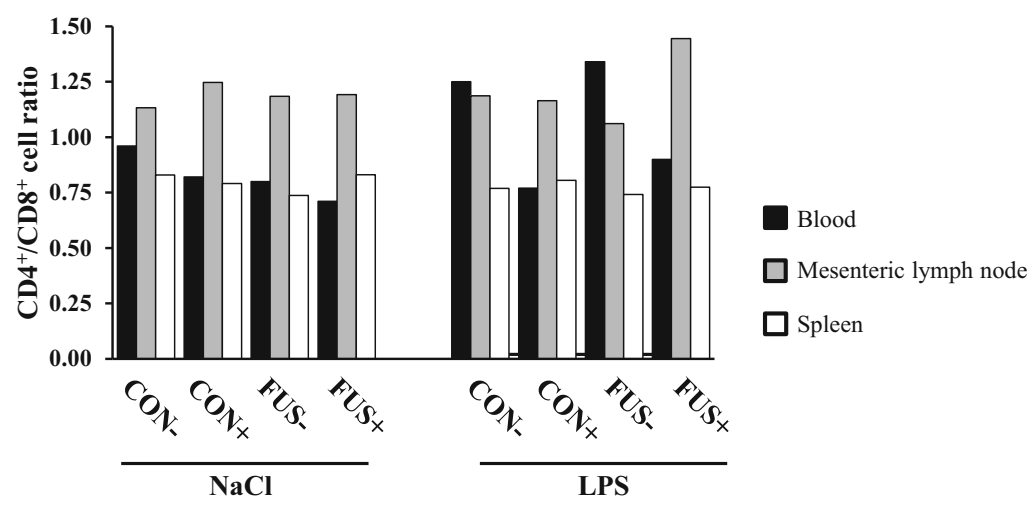

\begin{tabular}{|c|c|c|c|c|c|c|c|c|}
\hline & \multirow[b]{2}{*}{ PSEM } & \multicolumn{7}{|c|}{$p$-values } \\
\hline & & FUS & SoS & LPS & FUS*SoS & FUS*LPS & SoS*LPS & FUS*SoS*LPS \\
\hline Blood & 0.10 & 0.918 & 0.003 & 0.011 & 0.808 & 0.187 & 0.061 & 0.982 \\
\hline $\begin{array}{l}\text { Mesenteric } \\
\text { lymph node }\end{array}$ & 0.10 & 0.593 & 0.096 & 0.722 & 0.294 & 0.581 & 0.400 & 0.079 \\
\hline Spleen & 0.10 & 0.624 & 0.580 & 0.659 & 0.572 & 0.980 & 0.954 & 0.551 \\
\hline
\end{tabular}

PSEM: pooled standard error of means.

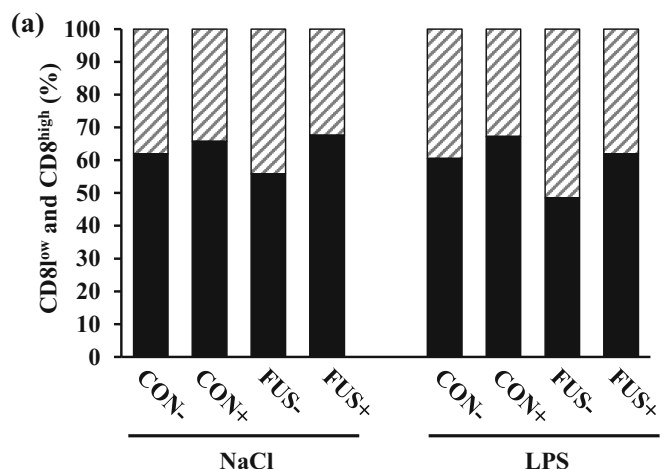

Fig. 3 Proportion of cytotoxic (a) CD8 ${ }^{\text {low }}$ and $\mathrm{CD} 8^{\text {high }} \mathrm{T}$ cells in blood (LSMeans, $n=5$ ) and their respective mean fluorescence intensity (MFI; b) in piglets receiving experimental diets for 5 weeks and subjected to a subsequent acute LPS challenge. Diets contained control (CON) or Fusarium-toxin contaminated maize (FUS), wet-conserved with or without $5 \mathrm{~g} \mathrm{SoS} / \mathrm{kg}$ maize sodium sulfite $(+/-)$ and piglets were injected with $7.5 \mu \mathrm{g}$ LPS $/ \mathrm{kg}$ $\mathrm{BW}$ or $0.9 \% \mathrm{NaCl}$
CD8 ${ }^{\text {low }}$

CD8 CDigh $^{\text {ha }}$

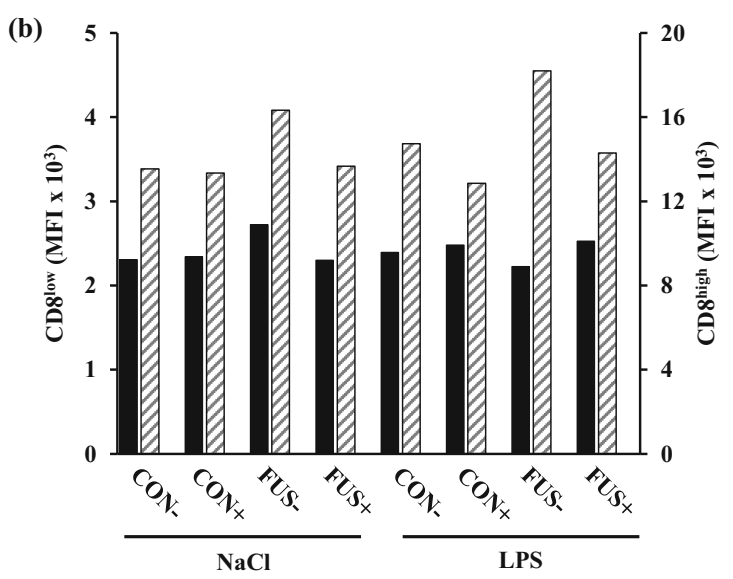

\begin{tabular}{lcccccccc}
\hline & & \multicolumn{7}{c}{$p$-values } \\
\cline { 3 - 8 } & PSEM & FUS & SoS & LPS & FUS*SoS & FUS*LPS & SoS*LPS & FUS*SoS*LPS \\
\hline Percentage & & & & & & & & \\
CD8 ${ }^{\text {low }}$ cells & 4.0 & 0.071 & $\mathbf{0 . 0 0 4}$ & 0.277 & 0.211 & 0.273 & 0.694 & 0.911 \\
CD8 ${ }^{\text {high }}$ cells & 4.0 & 0.071 & $\mathbf{0 . 0 0 4}$ & 0.277 & 0.211 & 0.273 & 0.694 & 0.911 \\
MFI & & & & & & & & \\
CD8 ${ }^{\text {low }}$ cells & 84.6 & 0.301 & 0.986 & 0.857 & 0.327 & $\mathbf{0 . 0 5 0}$ & $\mathbf{0 . 0 0 3}$ & $\mathbf{0 . 0 1 0}$ \\
CD8 ${ }^{\text {high }}$ cells & 849.9 & $\mathbf{0 . 0 0 3}$ & $\mathbf{0 . 0 0 1}$ & 0.197 & 0.076 & 0.470 & 0.237 & 0.857 \\
\hline
\end{tabular}

PSEM: pooled standard error of means. 
Fig. 4 Distribution of $\mathrm{CD} 21^{+} \mathrm{B}$ cells (a) in blood, mesenteric lymph node, and spleen (LSMeans, $n=5$ ) and their respective mean fluorescence intensity (MFI; b) in piglets receiving experimental diets for 5 weeks and subjected to a subsequent acute LPS challenge. Diets contained control (CON) or Fusarium-toxin contaminated maize (FUS), wet-conserved with or without $5 \mathrm{~g} \mathrm{SoS} / \mathrm{kg}$ maize sodium sulfite (+/-) and piglets were injected with $7.5 \mu \mathrm{g}$ LPS $/ \mathrm{kg}$ BW or $0.9 \% \mathrm{NaCl}$

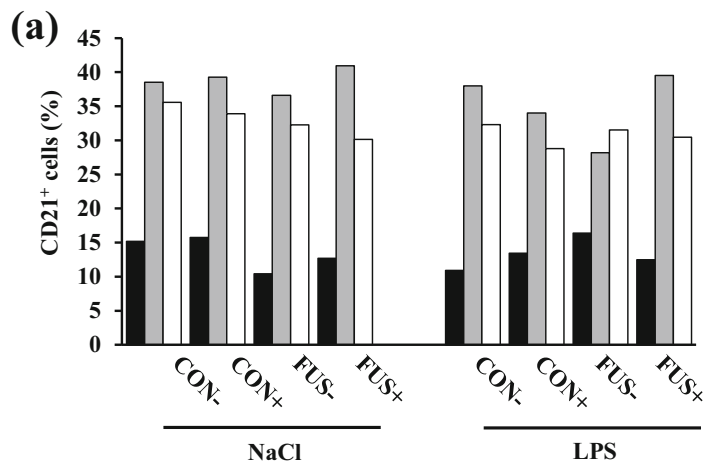

(b)

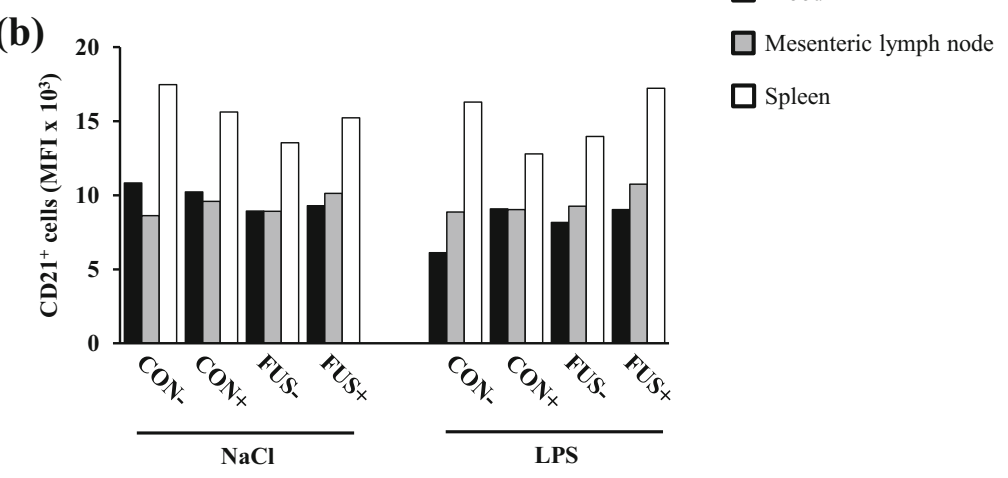

\begin{tabular}{|c|c|c|c|c|c|c|c|c|}
\hline & \multirow[b]{2}{*}{ PSEM } & \multicolumn{7}{|c|}{$p$-values } \\
\hline & & FUS & SoS & LPS & FUS*SoS & FUS*LPS & SoS*LPS & FUS*SoS*LPS \\
\hline \multicolumn{9}{|l|}{ Percentage } \\
\hline Blood & 1.6 & 0.466 & 0.748 & 0.851 & 0.296 & 0.009 & 0.351 & 0.077 \\
\hline $\begin{array}{l}\text { Mesenteric lymph } \\
\text { node }\end{array}$ & 3.5 & 0.644 & 0.215 & 0.121 & 0.064 & 0.685 & 0.819 & 0.241 \\
\hline Spleen & 2.7 & 0.423 & 0.278 & 0.256 & 0.790 & 0.304 & 0.920 & 0.699 \\
\hline \multicolumn{9}{|l|}{ MFI } \\
\hline Blood & 854.0 & 0.731 & 0.149 & 0.008 & 0.652 & 0.054 & 0.102 & 0.215 \\
\hline $\begin{array}{l}\text { Mesenteric lymph } \\
\text { node }\end{array}$ & 748.3 & 0.176 & 0.080 & 0.761 & 0.469 & 0.550 & 0.800 & 0.618 \\
\hline Spleen & 1656.4 & 0.644 & 0.930 & 0.738 & 0.036 & 0.181 & 0.985 & 0.497 \\
\hline
\end{tabular}

FUS and LPS: pooled groups $\mathrm{FUS} / \mathrm{NaCl}$ and CON/LPS were lower compared with their respective counterparts $\mathrm{CON} / \mathrm{NaCl}$ and FUS/LPS. The MFI of $\mathrm{CD} 21^{+}$cells in blood was significantly reduced in LPS-challenged pigs compared with their placebo counterparts. In spleen, an interaction between FUS and SoS treatment was evident: in CON-fed groups, SoS treatment $(\mathrm{CON}+)$ decreased MFI, whereas in their FUS counterparts, the situation was vice versa. There were no changes in $\mathrm{CD} 21^{+}$cells in mesenteric lymph node, neither in percentage nor in MFI.

Monocytes, identified as $\mathrm{CD} 14^{+}$cells by flow cytometry, showed a marked difference between blood, mesenteric lymph node, and spleen (Fig. 5): $<5 \%$ in blood, $\sim 20 \%$ in mesenteric lymph node, and $\sim 30 \%$ in spleen. In blood, percentage of $\mathrm{CD}_{14}{ }^{+}$cells was significantly decreased in LPSchallenged pigs ( $\mathrm{NaCl}$ vs. LPS: 3.9 vs. $2.0 \%$ ). In both lymphatic tissues, feeding FUS diets significantly increased the $\mathrm{CD} 14^{+}$proportion as compared with $\mathrm{CON}$ diets: in mesenteric lymph node from 17.5 to $21.5 \%$ and in spleen from 32.2 to $36.5 \%$. There were no significant changes due to other factors or a significant interaction between factors. The MFI of $\mathrm{CD}_{14}{ }^{+}$cells in blood, mesenteric lymph node, and spleen was not altered by any treatment and its values averaged at $1.5 \pm 0.2 \times 10^{3}, 2.5 \pm 0.3 \times 10^{3}$, and $2.6 \pm 0.2 \times 10^{3}$, respectively.

\section{Intracellular production of reactive oxygen species}

The basal ROS production $\left(=\mathrm{R} 123^{+}\right.$cells) was measured in PMN and PBMC and the percentage of positive cells as well as the MFI as functional marker is depicted in Fig. 6. Both the proportion of ROS-producing PMN (Fig. 6a) and PBMC (Fig. 6b) were significantly increased in LPS-challenged animals compared with their placebo counterparts. Moreover, the MFI in PMN (Fig. 6c) showed a significant interaction between SoS treatment and LPS challenge: whereas in $\mathrm{NaCl}$ 
Fig. 5 Proportion of CD14 ${ }^{+}$ monocytes in blood, mesenteric lymph node, and spleen (LSMeans, $n=5$ ) in piglets receiving experimental diets for 5 weeks and subjected to a subsequent acute LPS challenge. Diets contained control (CON) or Fusarium- toxin contaminated maize (FUS), wet-conserved with or without $5 \mathrm{~g} \mathrm{SoS} / \mathrm{kg}$ maize sodium sulfite $(+/-)$ and piglets were injected with $7.5 \mu \mathrm{g} \mathrm{LPS} / \mathrm{kg}$ $\mathrm{BW}$ or $0.9 \% \mathrm{NaCl}$

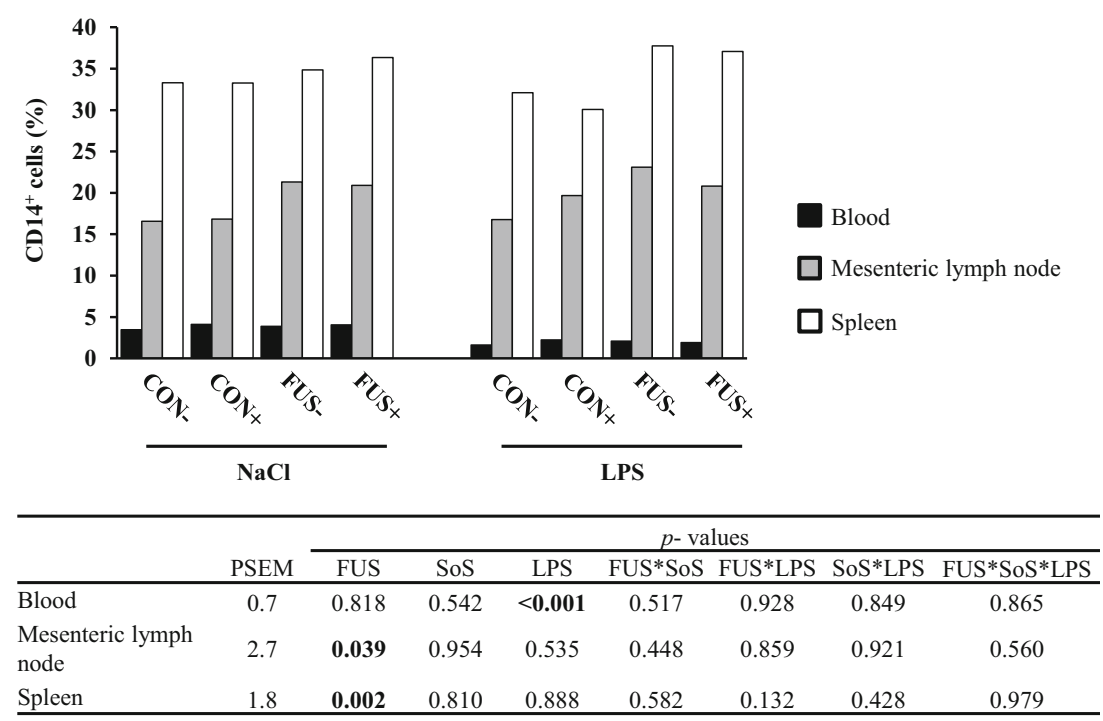

PSEM: pooled standard error of means. groups, there was no marked impact of SoS-treatment, SoStreatment resulted in a significant decrease in LPS-challenged groups. In PBMC, there was no impact on MFI (Fig. 6d). Both
PMN and PBCM were stimulated with TPA in order to induce an oxidative burst and both cell populations showed a clear increase in percentage (PMN 97.8 $\pm 0.7 \%$; PBMC $24.8 \pm$
Fig. 6 Intracellular basal (= nonstimulated) ROS production was evaluated in PMN (= granulocytes) and PBMC (incl. monocytes) with the fluochrome rhodamine R123 $\left(\mathrm{R} 123^{+}\right)$. The percentage of $\mathrm{R} 123^{+} \mathrm{PMN}$ (a) and PBMC (b) and their respective MFI values $(\mathbf{c}, \mathbf{d})$ are presented as LSMeans $(n=5)$. Piglets received experimental diets for 5 weeks and were subjected to a subsequent acute LPS challenge. Diets contained control (CON) or Fusariumtoxin contaminated maize (FUS), wet-conserved with or without $5 \mathrm{~g}$ $\mathrm{SoS} / \mathrm{kg}$ maize sodium sulfite $(+/-)$ and piglets were injected with $7.5 \mu \mathrm{g}$ LPS $/ \mathrm{kg}$ BW or $0.9 \%$ $\mathrm{NaCl}$ (a)

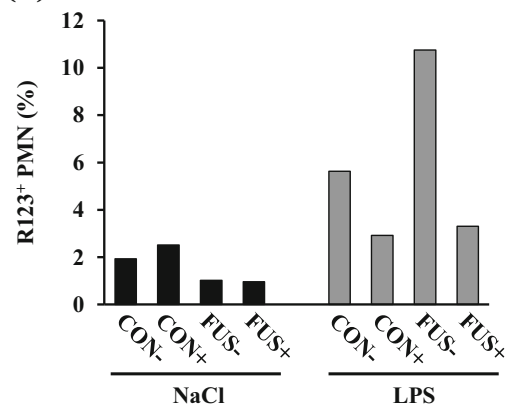

(b)

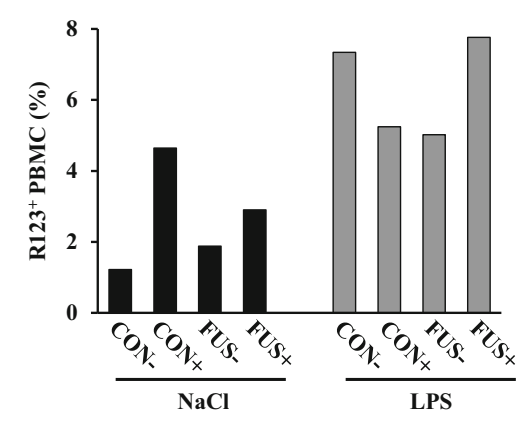

(c)

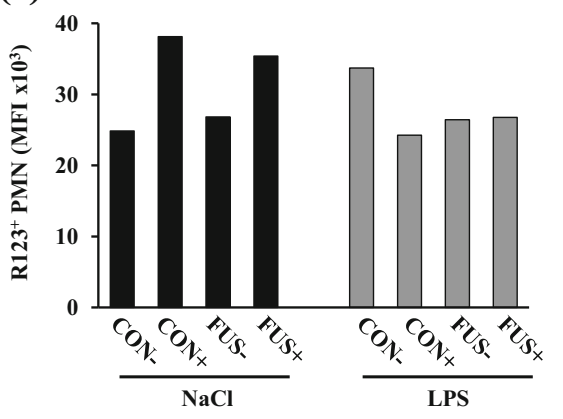

(d)

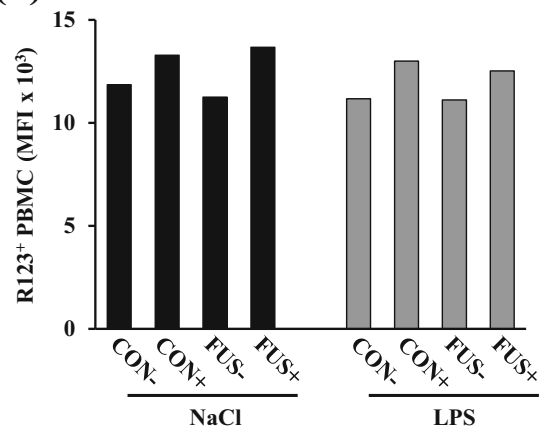

\begin{tabular}{|c|c|c|c|c|c|c|c|c|}
\hline & \multirow[b]{2}{*}{ PSEM } & \multicolumn{7}{|c|}{$p$-values } \\
\hline & & FUS & SoS & LPS & FUS*SoS & FUS*LPS & SoS*LPS & FUS*SoS*LPS \\
\hline \multicolumn{9}{|c|}{ ( } \\
\hline Percentage & 1.9 & 0.569 & 0.078 & 0.004 & 0.316 & 0.141 & 0.052 & 0.446 \\
\hline MFI & 4550.8 & 0.669 & 0.330 & 0.285 & 0.698 & 0.757 & 0.022 & 0.268 \\
\hline \multicolumn{9}{|l|}{ PBMC } \\
\hline Percentage & 1.6 & 0.851 & 0.284 & 0.003 & 0.604 & 0.785 & 0.421 & 0.130 \\
\hline MFI & 2350.8 & 0.912 & 0.294 & 0.736 & 0.932 & 0.964 & 0.925 & 0.833 \\
\hline
\end{tabular}


$5.4 \%$ ) and MFI (PMN $80.3 \pm 6.8 \times 10^{3}$; PBMC $99.0 \pm 21.3 \times$ $10^{3}$ ) after stimulation. This indicates that cells were capable of oxidative burst and responded well to the stimulation. However, stimulating properties and capacity of radical production in TPA-stimulated cells remained unaffected by any treatment in PMN and PBMC.

\section{Phagocytosis of PMN and PBMC}

Data on phagocytosis in PMN and PBMC population are represented in Fig. 7. The percentage of phagocytic PMN (Fig. 7a) was not altered by any treatment and remained at its mean value $69.5 \pm 5.3 \%$. However, we observed a significant increase in MFI of LPSchallenged pigs (Fig. 7c), indicating a higher phagocytic activity per cell in PMN. The percentage of phagocytic PBMC (Fig. 7b) was significantly altered as indicated by an interaction between factors FUS, SoS treatment, and LPS challenge: in CON-fed groups, LPS challenge decreased percentage of phagocytic cells, independent of
SoS presence. However, in FUS-fed groups the LPS effect was dependent on SoS presence: in group FUS - , the percentage of phagocytic cells slightly increased after LPS challenge, whereas in FUS+, the percentage markedly dropped. PBMC of LPS-challenged pigs showed a decrease in MFI (Fig. 7d), indicating a lower phagocytic activity per cell.

\section{Discussion}

Based on the cytotoxic effects of DON and sulfiting agents in general, and the reported interactive effects between SoS treatment of maize and LPS-induced systemic inflammation on the leukocyte count subsets in particular (Tran et al. 2018b), we hypothesized that DON and/or SoS treatment of maize would affect the immune traits with regard to the proportion of lymphocyte subsets as well as cellular function of granulocytes and monocytes.
Fig. 7 Phagocytic activity was evaluated in PMN (= granulocytes) and PBMC (= monocytes) with the use of FITClabelled E. coli bacteria. The percentage of phagocyting PMN (a) and PBMC (b) and their respective MFI values $(\mathbf{c}, \mathbf{d})$ are presented as LSMeans $(n=5)$.

Piglets received experimental diets for 5 weeks and were subjected to a subsequent acute LPS challenge. Diets contained control (CON) or Fusarium-

toxin contaminated maize (FUS), wet-conserved with or without $5 \mathrm{~g}$ $\mathrm{SoS} / \mathrm{kg}$ maize sodium sulfite $(+/-)$ and piglets were injected with $7.5 \mu \mathrm{g}$ LPS $/ \mathrm{kg} \mathrm{BW}$ or $0.9 \%$ $\mathrm{NaCl}$ (a)

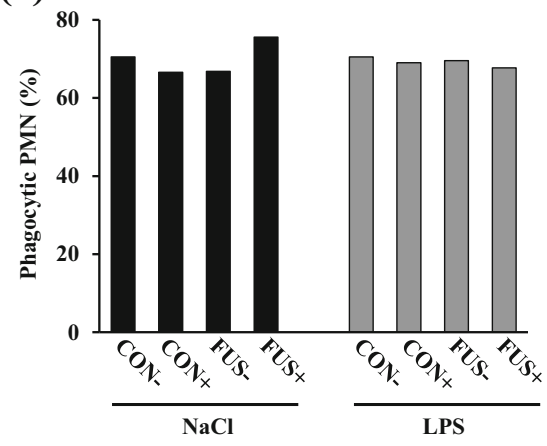

(c)

(b)

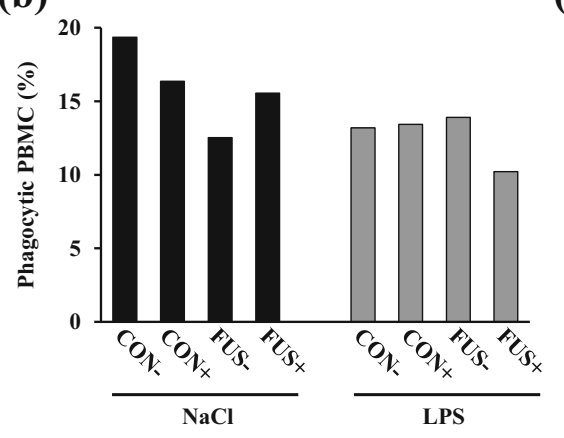

(d)

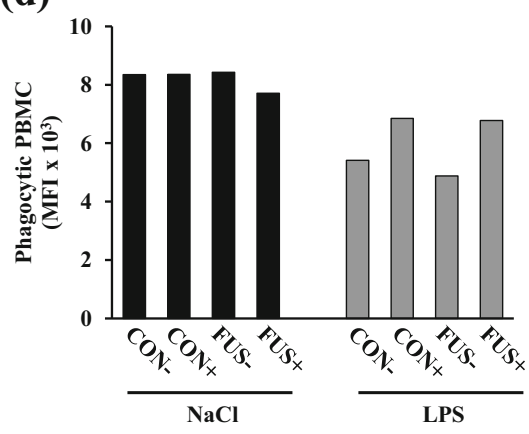

\begin{tabular}{lcccccccc}
\hline & & \multicolumn{7}{c}{$p$-values } \\
\cline { 3 - 8 } & PSEM & FUS & SoS & LPS & FUS*SoS & FUS*LPS & SoS*LPS & FUS*SoS*LPS \\
\hline PMN & & & & & & & & \\
Percentage & 5.3 & 0.846 & 0.921 & 0.869 & 0.436 & 0.633 & 0.604 & 0.408 \\
MFI & 5047.2 & 0.575 & 0.894 & $\mathbf{0 . 0 1 2}$ & 0.786 & 0.852 & 0.633 & 0.690 \\
PBMC & & & & & & & & \\
Percentage & 1.5 & $\mathbf{0 . 0 3 4}$ & 0.459 & $\mathbf{0 . 0 0 8}$ & 0.647 & 0.270 & 0.450 & $\mathbf{0 . 0 3 8}$ \\
MFI & 694.5 & 0.573 & 0.212 & $<\mathbf{0 . 0 0 1}$ & 0.899 & 0.986 & 0.059 & 0.568 \\
PSEM: pooled standard error of means. & & & & & & & & \\
\hline
\end{tabular}


LPS-induced systemic inflammation is based on a cascade of release of inflammatory mediators, vascular and physiological changes, and a recruitment of immune cells (van Amersfoort et al. 2003) resulting in a redistribution of immune cells between blood, lymph nodes, spleen, other organs and the site of the stimulus. Initial LPS response includes an activation of monocytes and macrophages due to binding simultaneously to the SCD14 (soluble form) in the blood and to the mCD14 (membrane-bound form) (Metkar et al. 2012). LPSactivated macrophages produce intracellular oxygen-free radicals and microbicidal agents and release various inflammatory mediators, which in turn initiate an acute phase reaction resulting in an array of effects on surrounding tissues (van Amersfoort et al. 2003). In agreement with literature, our results revealed a lower percentage of $\mathrm{CD} 14^{+}$cells in blood in LPS-challenged pigs. This observation is further substantiated by the LPS-reduced absolute monocyte counts in blood. Furthermore, our previous evaluation on the differential blood counts revealed an interactive effect between FUS maize, SoS treatment, and LPS injection for the monocyte counts with a general decrease due to LPS, a marked lower number in pooled groups FUS- and $\mathrm{CON}+$ compared with control group CON-, and an increase in group FUS+ (Tran et al. 2018b). In the present study, a higher percentage of $\mathrm{CD} 14^{+}$cells in both mesenteric lymph node and spleen in pigs fed FUS maize suggests a regulatory effect of DON on the migration of blood monocytes into lymphatic tissues.

As the first response of host defense, the innate immune cells including monocytes and neutrophils activate the phagocytosis and promote the release of oxygen free radicals, also called reactive oxygen species (ROS) in order to kill the invading microbial pathogen (Goodbourn et al. 2000; Fialkow et al. 2007). Although our results showed a significant threefactorial interaction between FUS maize, SoS treatment, and LPS injection for the percentage of phagocytosing PBMC, this effect was seemingly related to the LPS and DON impact with a general alteration in pooled LPS-challenged groups and in pooled FUS groups. Additionally, the significant lower MFI of phagocytosing PBMC in LPS-challenged pigs could reflect the impairment of LPS on the phagocytic activity per cell. In addition to phagocytosis, the release of ROS is responsible for killing the invading microorganism; however, it has been further suggested that an excessive ROS production leads to oxidative stress (Mishra et al. 2014). Besides, LPSinduced oxidative stress has been reported in various studies (Hsu and Wen 2002; Hsu and Liu 2004; Gasparrini et al. 2017). In accordance with the literature, our present results showed an increased proportion in basal ROS-generated PBMC in LPS-challenged pigs. Mitochondria are considered the center of metabolic pathway, a bioenergetic organelle with multiple functions such as energy supply, biosynthesis, and signaling platform for various innate immune signaling pathways. Recently, it has been reported that the mitochondrial respiratory chain in macrophages is adapted for contributing to antibacterial host defense due to ROS signaling to mitochondrial electron transport chain (Garaude et al. 2016). Thus, an increase for ROS generation in PBMC with LPS could reflect the increased metabolic activity and also increased energy demand in monocytes suggesting an impact of LPS on the mitochondrial respiratory chain.

Similar to monocytes/macrophages, the neutrophil granulocytes not only promote phagocytosis but also induce the ROS production in response to LPS (van Amersfoort et al. 2003). The significant effect of LPS on the MFI of phagocytosing granulocytes might be a reflection of a higher phagocytic activity per cell. Our results also revealed that LPS significantly increased the percentage of basal ROS production in granulocytes. Moreover, the significant interaction between SoS treatment and LPS on the MFI of basal ROS formation of PMN would suggest a SoS-modulated LPS effect on this cell type. These observations might be further supported by our previous data on the differential white blood counts, whereby an interactive effect between FUS maize and SoS treatment was observed for the amount of granulocytes with the higher number of granulocytes in the pooled group FUS+ compared with the group FUS- despite a general LPS reduction (Tran et al. 2018b). In a study with human PBMC, Winkler et al. (2006) concluded that SoS suppressed the release of cytokine INF- $\gamma$, which is the most important mediator responsible for ROS formation (Karin and Greten 2005; Winkler et al. 2006). Thus, SoS may act as an antioxidant preventing ROS formation due to a reduced INF- $\gamma$ release, which however was not measured in our study.

The present data revealed that the alterations of $\mathrm{T}$ lymphocyte subsets mostly occurred in the peripheral blood samples. In blood, higher proportions of $\mathrm{CD}^{+} \mathrm{T}$ cells, the socalled $\mathrm{T}$ helper cells, were observed in LPS-treated piglets, confirming an activated state of the immune system (Gerner et al. 2009; Gerner et al. 2015) after the LPS challenge. This interpretation is further supported by the $\mathrm{CD} 4^{+} / \mathrm{CD}^{+}$cell ratio, which is regarded as critical in maintaining a stable immunological function (Dou et al. 2013). Looking closer, LPS injection induced an increase of $\mathrm{CD} 4^{+} / \mathrm{CD}^{+}$cell ratio in LPS-challenged piglets, which agreed well with the findings of another study using a similar LPS challenge protocol in rearing piglets (Stelter et al. 2013). With regard to SoS treatment, lower proportions of $\mathrm{CD}^{+}{ }^{+} \mathrm{T}$ cells in blood were found in pigs receiving SoS treated maize, which resulted in lower $\mathrm{CD}^{+} / \mathrm{CD}^{+}$ratio. Winkler et al. (2006) demonstrated in an in vitro study on human PBMC that the food preservative SoS had a suppressive impact on activated $\mathrm{T}$ helper cells of the type Th1. Therefore, the SoS-related reduction of $\mathrm{CD} 4^{+} \mathrm{T}$ cells and a change of $\mathrm{CD} 4^{+} / \mathrm{CD}^{+}$ratio in our study might be partially attributed to the impact on Th1 cell functionality. Moreover, the release of cytokines is considered the crucial factors for activation of T helper cell types such as IFN- $\gamma$, IL- 
2, IL-12 (Th1) and IL-4, IL-5, IL-9 (Th2) which however were not measured in the present study (Romagnani 2004; Murr et al. 2005; Winkler et al. 2006).

In the literature, the higher percentage of porcine doublepositive $\mathrm{T}$ cells $\left(\mathrm{CD} 3^{+} \mathrm{CD} 4^{+} \mathrm{CD} 8^{+}\right)$in blood and lymphoid organs as compared with humans has been reported (Zuckermann and Husmann 1996; Waters et al. 1999; Zuckermann 1999). Our results revealed an increase in double-positive $\mathrm{T}$ cells in blood when pigs were fed FUStoxin contaminated maize. Moreover, the significant interaction between FUS maize and LPS challenge for doublepositive cells in mesenteric lymph node might reflect a DON-related effect since the percentage of double-positive $\mathrm{T}$ cells was only decreased in the pooled group FUS/NaCl. Contrarily, a tendency of an interactive effect between FUS maize and LPS challenge in blood ( $p_{\text {FUS } * \text { LPS }}=0.078$, Fig. 1 ) was observed due to an increase in the pooled group FUS/ $\mathrm{NaCl}$. Therefore, the higher percentage of double-positive $\mathrm{T}$ cells in blood might be related to migrating cells from secondary lymphoid organs such as mesenterial lymph nodes into peripheral blood. The double-positive $\mathrm{T}$ cells are considered memory cells and play a role in protective immunity and immune regulation (Zuckermann 1999).

For the double-negative $\mathrm{T}$ cells $\left(\mathrm{CD}^{+}{ }^{+} \mathrm{CD}^{-}{ }^{-} \mathrm{CD} 8^{-}\right)$, similar observations have been made: a decrease of this cell type in spleen, whereas a marked increase in blood in pigs fed FUS maize. It has been suggested that in thymus, the doublenegative $\mathrm{CD} 4^{-} \mathrm{CD} 8^{-}$precursor cells differentiate into $\mathrm{CD} 4^{+} \mathrm{CD} 8^{+}$thymocytes, which upon further differentiation lose either $\mathrm{CD} 4$ or $\mathrm{CD} 8$, giving rise to the mature $\mathrm{CD} 4^{+}$and $\mathrm{CD} 8^{+}$single-positive cells (Gerner et al. 2015). In mise, the extrathymic double-negative $\mathrm{T}$ cells seemingly relate to defective differentiation. However, analyses of porcine $\mathrm{T}$ cells in blood and secondary lymphatic organs revealed several peculiarities compared with humans and rodent species, whereby the presence of double-negative $\mathrm{T}$ cells are predominant in spleen (Saalmüller et al. 1987). Moreover, it has been proposed that the double-negative cells are not homogeneous and might also comprise other subpopulations including B cells and monocytes (Arriëns et al. 1998). Thus, the immune-modulating effects of DON on the double-negative cells might be associated with the alteration of other immune cell types. Our data indicate that the significant impact of FUS maize was only evident in double-positive or double-negative $\mathrm{T}$ cell subsets. In the frame of our experimental setup, we are unable to address whether double-negative cells lose their epitopes and transform into double-negative cells or differentiate in other subsets (i.e., $\mathrm{CD} 8^{+}$).

Although the alteration of T cell subpopulation only occasionally occurred in the lymphatic tissues, the present results demonstrated significant three-factorial interaction for $\mathrm{CD} 8^{+}$ $\mathrm{T}$ cells in mesenteric lymph node. It seemed that SoS treatment only of the FUS-contaminated maize group (FUS+/LPS) prevented the LPS-induced increase of $\mathrm{CD} 8^{+} \mathrm{T}$ cell proportion observed in group FUS-/LPS. This observation might be related to the presence of DON sulfonates, both in systemic and local immune system.

It has been suggested that swine showed a higher percentage of $\mathrm{CD} 8^{+} \mathrm{T}$ cells in blood compared with humans (Lunney and Pescovitz 1987; Saalmüller et al. 1989; Lorenzen et al. 2015). The $C D 8^{+} \mathrm{T}$ cells are known as cytotoxic cells and can attack directly pathogen-infected cells (Gerner et al. 2009). Therefore, it was of interest to examine the $\mathrm{CD} 8^{+} \mathrm{T}$ cell subsets, which can be subdivided into $\mathrm{CD} 8^{\text {low }}$ and $\mathrm{CD} 8^{\text {high }}$ subsets. $\mathrm{CD} 8^{\text {high }}$ subset is considered the cytotoxic $\mathrm{T}$ cells due to a strong cytolytic activity (Gerner et al. 2009), whereas $\mathrm{CD} 8^{\text {low }}$ cells might act as T helper-like cells due to the expression of IFN- $\gamma$ and IL-4, the signature cytokines of type 1 (Th1) and 2 (Th2) T cells (Lunney and Pescovitz 1987). The effect of DON on both subsets was rarely examined and showed no effect on the $\mathrm{CD} 8^{\text {high }}$ subset in pigs fed diet containing $0.5 \mathrm{mg}$ DON (Ferrari et al. 2009). Contrarily, present results suggested that the MFI (giving an indication of the density of CD epitopes) of CD $8^{\text {high }}$ cells in pigs fed FUS maize was increased which was paralleled by a slightly higher percentage of $\mathrm{CD} 8^{\text {high }}$ cells, suggesting that dietary exposure to DON might change the cytotoxic $\mathrm{T}$ cell function due to increased expression of CD8 receptor on the T cell surface. The DON effect on the immune response is considered to depend on dose, exposure frequency, and timing of functional immune assay (Pestka et al. 2004). Thus, the reason for the different results between studies might be associated with higher dosage of DON, which was about ten-fold higher in our study.

With regard to SoS treatment, our data revealed significant SoS effects on both $\mathrm{CD} 8^{\text {low }}$ and CD $8^{\text {high }}$ cells. Studies on the SoS toxicity showed that SoS has a very low level of mammalian toxicity and is free from carcinogenic activity (Nair and Elmore 2003). Once ingested, SoS and other sulfite salts are metabolized to sulfate by the enzyme sulfite oxidase which is excreted and less toxic than sulfite (Dänicke et al. 2012). However, this conversion is determined by the species-specific enzyme activity (Tejnorova 1978) and appears to be incomplete. Moreover, a very low level of sulfite oxidase activity was found in macrophages and neutrophils compared with other cell types such as hepatocytes. Consequently, non-metabolized sulfite might affect these cell types (Beckspeier et al. 1985). It was shown that sulfite did not suppress the cell viability (Winkler et al. 2006). Additionally, an amount of sulfite still existed in blood when pigs were fed SoS-treated maize, although a higher whole sulfuric concentration was not observed in groups compared with control groups (Tran et al. 2018a). Therefore, these present sulfite concentrations might affect immune cells due to the alteration of CD8 epitope expression. 
CD21 is only expressed by mature B cells and the proportion of this cell type is regarded as an indicator for B cell development (Axcrona et al. 1996). Present results demonstrated that the $\mathrm{CD} 21^{+} \mathrm{B}$ cell proportion in blood was altered due to an interactive effect between FUS and LPS. This observation is further supported by a similar alteration of lymphocyte counts in blood as published earlier (Tran et al. 2018b): a decrease of lymphocytes in group FUS $-/ \mathrm{NaCl}$ and $\mathrm{CON}-/ \mathrm{LPS}$, but an increase of this cell type in group FUS-LPS. In addition, a tendency $\left(p_{\text {FUSxLPS }}=0.054\right)$ for opposing effects of FUS maize and LPS injection on MFI of CD2 $1^{+}$cells in blood was also observed with a similar reduction in pooled groups FUS/ $\mathrm{NaCl}$ and $\mathrm{CON} /$ LPS, suggesting a suppressive effect of DON and LPS on the circulating B cells and might reflect the migration activity of this cell type. However, this putative migration was not paralleled by an altered B cell percentage in lymphatic organs. Interestingly, the significant interaction between FUS maize and SoS treatment for the MFI of splenic CD21 ${ }^{+}$B cells could hint at a DONrelated effect since the MFI level was higher in group FUS+, which reflects some alterations in the expression of CD21 molecules on the B cell surface in lymphatic organs. The CD21 epitope as an indicator for B cell development interacts with $\mathrm{CD} 2$ and forms the $\mathrm{CD} 2 / \mathrm{CD} 21 \mathrm{com}-$ plex, leading to further differentiation of mature B cells. The latter CD2 expression, however, was not measured in our study.

DON might affect immune traits, especially the immunoglobulin A (IgA) production as a specific effect of DON (Döll and Dänicke 2011; Pestka 2003), whereas DON effects on B cells itself were rarely investigated. In horse, Khol-Parisini et al. (2012) observed no effect of DON on the $\mathrm{CD} 21^{+} \mathrm{B}$ cells when horses were fed highly DON-contaminated oat with $20.2 \mathrm{mg} \mathrm{DON} / \mathrm{kg}$ oat. Other studies with mice reported that DON has no direct impact on the primary B cells from Peyer's patches or spleen or in cloned B cells, but rather indirectly due to the influence on the $\mathrm{T}$ cell subpopulations and macrophages (Pestka 2003).

In conclusion, the results of this study indicate that alterations in the subpopulations of lymphocytes and monocytes mostly occurred in the peripheral blood and only occasionally in the investigated mesenteric lymph node and spleen tissues. In particular, SoS treatment of maize altered the T-lymphocyte subpopulations in blood with a more pronounced effect on $\mathrm{CD} 8^{\text {low }}$ and $\mathrm{CD} 8^{\text {high }}$ subsets, whereas impact of FUS was more notable on the doublepositive T cells in the lymphatic tissues. Furthermore, SoS treatment of maize partially suppressed the magnitude of an LPS effect on cellular function, irrespective of diet. Further studies are needed to elucidate the observed effects, in particular with regard to cell function in the various subsets and tissues.
Acknowledgments The authors thank the co-workers of the Institute of Animal Nutrition and the experimental station of the Friedrich-LoefflerInstitut in Braunschweig for their assistance in performing the experiment and analyses.

Funding Open Access funding provided by Projekt DEAL. The authors would like to thank Biomin Holding GmbH (Tulln, Austria) for financial support.

\section{Compliance with ethical standards}

The experiment was performed at the experimental station of the Institute of Animal Nutrition, Friedrich-Loeffler-Institute (FLI), Brunswick, Germany, in compliance with the European Community regulations concerning the protection of experimental animals and was approved by the Lower Saxony State Office for Consumer Protection and Food Safety (LAVES), Germany (file number: 33.92-42502-04-13/1153).

Conflict of interest The authors declare that they have no conflict of interest.

Open Access This article is licensed under a Creative Commons Attribution 4.0 International License, which permits use, sharing, adaptation, distribution and reproduction in any medium or format, as long as you give appropriate credit to the original author(s) and the source, provide a link to the Creative Commons licence, and indicate if changes were made. The images or other third party material in this article are included in the article's Creative Commons licence, unless indicated otherwise in a credit line to the material. If material is not included in the article's Creative Commons licence and your intended use is not permitted by statutory regulation or exceeds the permitted use, you will need to obtain permission directly from the copyright holder. To view a copy of this licence, visit http://creativecommons.org/licenses/by/4.0/.

\section{References}

Awad WA, Ghareeb K, Böhm J, Zentek J (2010) Decontamination and detoxification strategies for the Fusarium mycotoxin deoxynivalenol in animal feed and the effectiveness of microbial biodegradation. Food Addit Contam 27:510-520

Arriëns MA, Summerfield A, McCullough KC (1998) Differential adhesion molecule expression on porcine mononuclear cell populations. Scand J Immunol 47:487-495

Axcrona K, Gray D, Leanderson T (1996) Regulation of B cell growth and differentiation via CD21 and CD40. Eur J Immunol 26:22032207

Beckspeier I, Hinze H, Holzer H (1985) Effect of sulphite on the energymetabolism of mamalian-tissues in correlation to sulphite oxidase activity. Biochim Biophys Acta 841:81-89

Crispe IN (2009) The liver as a lymphoid organ. Annu Rev Immunol 27: $147-163$

Dänicke S, Beineke A, Goyarts T, Valenta H, Beyer M, Humpf HU (2008) Effects of a Fusarium-toxin contaminated triticale, either untreated or treated with sodium metabisulphite $\left(\mathrm{Na}_{2} \mathrm{~S}_{2} \mathrm{O}_{5}, \mathrm{SBS}\right)$, on weaned piglets with a special focus on liver function as determined by the ${ }^{13} \mathrm{C}$-methacetin breath test. Arch Anim Nutr 62:263286

Dänicke S, Brüssow KP, Valenta $\mathrm{H}$, Ueberschar KH, Tiemann U, Schollenberger M (2005) On the effects of graded levels of Fusarium-toxin contaminated wheat in diets for gilts on feed intake, growth performance and metabolism of deoxynivalenol and zearalenone. Mol Nutr Food Res 49:932-943 
Dänicke S, Kersten S, Valenta H, Breves G (2012) Inactivation of deoxynivalenol-contaminated cereal grains with sodium metabisulphite: a review of procedures and toxicological aspects. Mycotoxin Res 28:199-218

Dänicke S, Brosig B, Kersten S, Kluess J, Kahlert S, Panther P, Diesing A-K, Rothkötter H-J (2013) The Fusarium toxin deoxynivalenol (DON) modulates the LPS induced acute phase reaction in pigs. Toxicol Lett. 220:172-180

Döll S, Dänicke S (2011) The Fusarium toxins deoxynivalenol (DON) and zearalenone (ZON) in animal feeding. Prev Vet Med 102:132145

Dou X, Wang RB, Yan HJ, Jiang SM, Meng XJ, Zhu KL, Xu XQ, Mu DB (2013) Circulating lymphocytes as predictors of sensitivity to preoperative chemoradiotherapy in rectal cancer cases. Asian Pac J Cancer P 14:3881-3885

EFSA (2004) Opinion of the Scientific Panel on contaminants in the food chain on a request from the commission related to Deoxynivalenol (DON) as undesirable substance in animal feed. EFSA J 73:1-41. https://doi.org/10.2903/j.efsa.2004.73

EFSA (2013) Deoxynivalenol in food and feed: occurrence and exposure. EFSA J 11. https://doi.org/10.2903/j.efsa.2013.3379

Ferrari L, Cantoni AM, Borghetti P, De Angelis E, Corradi A (2009) Cellular immune response and immunotoxicity induced by DON (deoxynivalenol) in piglets. Vet Res Commun 33(Suppl 1):133-135

Fialkow L, Wang Y, Downey GP (2007) Reactive oxygen and nitrogen species as signaling molecules regulating neutrophil function. Free Radic Biol Med 42:153-164

Gasparrini M, Forbes-Hernandez TY, Giampieri F, Afrin S, AlvarezSuarez JM, Mazzoni L, Mezzetti B, Quiles JL, Battino M (2017) Anti-inflammatory effect of strawberry extract against LPS-induced stress in RAW 264.7 macrophages. Food Chem Toxicol 102:1-10

Garaude J, Acín-Pérez R, Martínez-Cano S, Enamorado M, Ugolini M, Nistal-Villán E, Hervás-Stubbs S, Pelegrín P, Sander LE, Enríquez JA, Sancho D (2016) Mitochondrial respiratory-chain adaptations in macrophages contribute to antibacterial host defense. Nat Immunol 17:1037-1045

Gerner W, Kaser T, Saalmüller A (2009) Porcine T lymphocytes and NK cells-an update. Dev Comp Immunol 33:310-320

Gerner W, Talker SC, Koinig HC, Sedlak C, Mair KH, Saalmüller A (2015) Phenotypic and functional differentiation of porcine alphabeta T cells: current knowledge and available tools. Mol Immunol 66:3-13

Goodbourn S, Didcock L, Randall RE (2000) Interferons: cell signalling, immune modulation, antiviral response and virus countermeasures. J Gen Virol 10:2341-2364

He JW, Zhou T, Young JC, Boland GJ, Scott PA (2010) Chemical and biological transformations for detoxification of trichothecene mycotoxins in human and animal food chains: a review. Trends Food Sci Tech 21:67-76

Hsu DZ, Liu MY (2004) Sesame oil protects against lipopolysaccharidestimulated oxidative stress in rats. Crit Care Med 32:227-231

Hsu HY, Wen MH (2002) Lipopolysaccharide-mediated reactive oxygen species and signal transduction in the regulation of interleukin-1 gene expression. J Biol Chem 277:22131-22139

Ji AJ, Savon SR, Jacobsen DW (1995) Determination of total serum sufite by HPLC with fluorescence detection. Clin Chem 41:897-903

Kabak B, Dobson AD, Var I (2006) Strategies to prevent mycotoxin contamination of food and animal feed: a review. Crit RevFood Sci 46:593-619

Karin M, Greten FR (2005) NF-kappaB: linking inflammation and immunity to cancer development and progression. Nat Rev Immunol 5: 749-759

Khol-Parisini A, Hellweg P, Razzazi-Fazeli E, Saalmuller A, Strasser A, Tichy A, Zentek J (2012) Highly deoxynivalenol contaminated oats and immune function in horses. Arch Anim Nutr 66:149-161
Kuzmich NN, Sivak KV, Chubarev VN, Porozov YB, SavateevaLyubimova TN, Peri F (2017) TLR4 signaling pathway modulators as potential therapeutics in inflammation and sepsis. Vaccines 5:34 59

Lorenzen E, Follmann F, Jungersen G, Agerholm JS (2015) A review of the human vs. porcine female genital tract and associated immune system in the perspective of using minipigs as a model of human genital Chlamydia infection. Vet Res 46:116-129

Lunney JK, Pescovitz MD (1987) Phenotypic and functional characterization of pig lymphocyte populations. Vet Immunol Immunopathol 17:135-144

Mishra S, Dwivedi PD, Pandey HP, Das M (2014) Role of oxidative stress in Deoxynivalenol induced toxicity. Food Chem Toxicol 72: 20-29

Murr C, Schroecksnadel K, Winkler C, Ledochowski M, Fuchs D (2005) Antioxidants may increase the probability of developing allergic diseases and asthma. Med Hypotheses 64:973-977

Nair B, Elmore AR (2003) Final report on the safety assessment of sodium sulphite, potassium sulphite, ammonium sulphite, sodium bisulphite, ammonium bisulphite, sodium metabisulphite and potassium metabisulphite. Int J Toxicol 22:63-88

Palsson-McDermott EM, O'Neill LA (2004) Signal transduction by the lipopolysaccharide receptor, Toll-like receptor-4. Immunology 113: 153-162

Paulick M, Rempe I, Kersten S, Schatzmayr D, Schwartz-Zimmermann HE, Dänicke S (2015) Effects of increasing concentrations of sodium sulfite on deoxynivalenol and deoxynivalenol sulfonate concentrations of maize kernels and maize meal preserved at various moisture content. Toxins 7:791-811

Paulick M, Winkler J, Kersten S, Schatzmayr D, Frahm J, Kluess J, Schwartz-Zimmermann HE, Dänicke S (2018) Effects of oral exposure to sodium sulphite-treated deoxynivalenol (DON)-contaminated maize on performance and plasma concentrations of toxins and metabolites in piglets. Arch Anim Nutr 72:42-57

Pestka JJ (2003) Deoxynivalenol-induced IgA production and IgA nephropathy-aberrant mucosal immune response with systemic repercussions. Toxicol Lett 140-141:287-295

Pestka JJ, Zhou HR, Moon Y, Chung YJ (2004) Cellular and molecular mechanisms for immune modulation by deoxynivalenol and other trichothecenes: unraveling a paradox. Toxicol Lett 153:61-73

Renner L, von Soosten D, Sipka A, Döll S, Beineke A, Schuberth H-J, Dänicke S (2012) Effect of conjugated linoleic acid on proliferation and cytokine expression of bovine peripheral blood mononuclear cells and splenocytes ex vivo. Arch Anim Nutr 66:73-85

Romagnani S (2004) Immunologic influences on allergy and the TH1/ TH2 balance. J. Allergy Clin. Immunol 113:395-400

Saalmüller A, Reddehase MJ, Bühring HJ, Jonjić S, Koszinowski UH (1987) Simultaneous expression of CD4 and CD8 antigens by a substantial proportion of resting porcine $\mathrm{T}$ lymphocytes. Eur $\mathrm{J}$ Immunol 17:1297-1301

Saalmüller A, Hirt W, Reddehase MJ (1989) Phenotypic discrimination between thymic and extrathymic CD4-CD8- and CD4+CD8+ porcine T lymphocytes. Eur J Immunol 19:2011-2016

Schwartz-Zimmermann HE, Paulick M, Dänicke S, Schatzmayr D, Berthiller F (2014) Determination of deoxynivalenol sulphonates in cereal samples: method development, validation and application. World Mycotoxin J 7:233-245

Schwartz HE, Hametner C, Slavik V, Greitbauer O, Bichl G, KunzVekiru E, Schatzmayr D, Berthiller F (2013) Characterization of three deoxynivalenol sulfonates formed by reaction of deoxynivalenol with sulfur reagents. J Agric Food Chem 61:89418948

Solano-Aguilar GI, Vengroski KG, Beshah E, Lunney JK (2000) Isolation and purification of lymphocyte subsets from gutassociated lymphoid tissue in neonatal swine. J Immunol Methods 241:185-199 
Stelter K, Frahm J, Paulsen J, Berk A, Kleinwachter M, Selmar D, Dänicke S (2013) Effects of oregano on performance and immunmodulating factors in weaned piglets. Arch Anim Nutr 67: $461-476$

Tejnorova I (1978) Sulphite oxidase activity in liver and kidney tissue in five laboratory animal species. Toxicol Appl Pharmacol 44:251256

Tran AT, Kluess J, Berk A, Paulick M, Frahm J, Schatzmayr D, Winkler J, Kersten S, Dänicke S (2018a) Detoxification of Fusarium-contaminated maize with sodium sulphite - in vivo efficacy with special emphasis on mycotoxin residues and piglet health. Arch Anim Nutr 72:58-75

Tran AT, Kluess J, Berk A, Paulick M, Frahm J, Schatzmayr D, Kersten S, Dänicke S (2018b) Effects of a Fusarium-toxin contaminated maize treated with sodium sulphite on male piglets in the presence of an LPS-induced acute inflammation. Toxins (Basel) 10:419. https://doi.org/10.3390/toxins 10100419

van Amersfoort ES, van Berkel TJ, Kuiper J (2003) Receptors, mediators, and mechanisms involved in bacterial sepsis and septic shock. Clin Microbiol Rev 16:379-414

Waters WR, Pesch BA, Hontecillas R, Sacco RE, Zuckermann FA, Wannemuehler MJ (1999) Cellular immune responses of pigs induced by vaccination with either a whole cell sonicate or pepsin- digested Brachyspira (Serpulina) hyodysenteriae bacterin. Vaccine 18:711-719

Winkler C, Frick B, Schroecksnadel K, Schennach H, Fuchs D (2006) Food preservatives sodium sulphite and sorbic acid suppress mitogen-stimulated peripheral blood mononuclear cells. Food Chem Toxicol 44:2003-2007

Wyns H, Plessers E, de Backer P, Meyer E, Croubels S (2015) In vivo porcine lipopolysaccharide inflammation models to study immunomodulation of drugs. Vet Immunol Immunopathol 166: $58-69$

Young JC, Trenholm HL, Friend DW, Prelusky DB (1987) Detoxification of deoxynivalenol with sodium bisulphite and evaluation of the effects when pure mycotoxin or contaminated corn was treated and given to pigs. J Agric Food Chem 35:259-261

Zuckermann FA (1999) Extrathymic CD4/CD8 double positive T cells. Vet Immunol Immunopathol 72:55-66

Zuckermann FA, Husmann RJ (1996) Functional and phenotypic analysis of porcine peripheral blood CD4/CD8 double-positive T cells. Immunology 87:500-512

Publisher's note Springer Nature remains neutral with regard to jurisdictional claims in published maps and institutional affiliations. 